ISSN 0258-7122

Bangladesh J. Agril. Res. 39(4): 631-640, December 2014

\title{
EFFECT OF NITROGEN, PHOSPHORUS, POTASSIUM AND SULPHUR ON THE YIELD OF MANGO
}

\author{
SHAMIMA NASREEN ${ }^{1}$, A. M. KAMAL ${ }^{2}$, M. A. SIDDIKY ${ }^{3}$ \\ R. P. RANNU ${ }^{4}$ AND M. S. ISLAM ${ }^{5}$
}

\begin{abstract}
The experiment was conducted at the research field of Regional Horticulture Research Station, Chapai Nawabganj during 2010-11, 2011-12 and 2012-13 to find out the proper combination of fertilizer nutrients $(\mathrm{N}, \mathrm{P}, \mathrm{K}$ and $\mathrm{S})$ in presence of organic manure for obtaining higher yield of mango (var. BARI Aam-1). The treatments were native nutrient i.e. control $\left(\mathrm{T}_{1}\right), \mathrm{N}_{360} \mathrm{P}_{80} \mathrm{~K}_{150} \mathrm{~S}_{50}$ $\left(\mathrm{T}_{2}\right), \quad \mathrm{N}_{560} \mathrm{P}_{120} \mathrm{~K}_{200} \mathrm{~S}_{70}\left(\mathrm{~T}_{3}\right), \quad \mathrm{N}_{760} \mathrm{P}_{160} \mathrm{~K}_{250} \mathrm{~S}_{90}\left(\mathrm{~T}_{4}\right), \quad \mathrm{N}_{960} \mathrm{P}_{200} \mathrm{~K}_{300} \mathrm{~S}_{110} \quad\left(\mathrm{~T}_{5}\right)$, and $\mathrm{N}_{1100} \mathrm{P}_{300} \mathrm{~K}_{500} \mathrm{~S}_{120}$ i.e. farmers practice $\left(\mathrm{T}_{6}\right) \mathrm{g} /$ tree/year. In addition, $20 \mathrm{~kg}$ cowdung/tree was used as blanket dose. Number of fruits/tree, individual fruit weight, fruit size, stone weight, peel weight, TSS content and yield of mango varied significantly due to variations of nutrients in all the years. The highest yield and yield attributes were recorded under treatment $\mathrm{N}_{960} \mathrm{P}_{200} \mathrm{~K}_{300} \mathrm{~S}_{110} \mathrm{~g} /$ tree and it was statistically identical with $\mathrm{N}_{760} \mathrm{P}_{160} \mathrm{~K}_{250} \mathrm{~S}_{90} \mathrm{~g} /$ tree. The lowest yield was obtained from untreated control plot (native nutrient). The yield benefit for the best treatment $\left(\mathrm{T}_{5}\right)$ over the control was $86 \%$ in $2010-11,64 \%$ in $2011-12$ and $73 \%$ in 2012-13. The highest gross margin (Tk 2509/tree in 2010-11, Tk 2651/tree in 2011-12 and Tk 2478/tree in 2012-13) and marginal rate of return (2375\% in $2010-11,2225 \%$ in $2011-12$ and $2300 \%$ in 2012-13) was also obtained from the same treatment. Three years' study revealed that application of $\mathrm{N}_{960} \mathrm{P}_{200} \mathrm{~K}_{300} \mathrm{~S}_{110} \mathrm{~g} /$ tree along with a blanket dose of $20 \mathrm{~kg}$ cowdung/tree appears to be the best treatment and economically optimum for achieving higher yield of mango in Chapai Nawabganj region.
\end{abstract}

\section{Introduction}

Mango (Mangifera indica L.) belongs to the family Anacardiaceae, originated in South Asia or Malayan archipelago (Mukherjee, 1997). It is lucrative, tasty and rich in vitamins and minerals. Popularly called "King of fruit". In Bangladesh, in terms of total area and production of fruit crops, mango ranks first in area and third in production. It occupies 1.53 lakh hectares of land and total production is 2.99 lakh metric tons per annum with an average yield of $1.95 \mathrm{t} / \mathrm{h}$ (BBS, 2012).

${ }^{1}$ Chief Scientific Officer, Horticulture Research Centre, Bangladesh Agricultural Research Institute (BARI), Gazipur, ${ }^{2}$ Scientific Officer, Regional Horticulture Research Station, Chapai Nawabganj, ${ }^{3}$ Senior Scientific Officer, Soil \& Water Management Section, HRC, BARI, Gazipur, ${ }^{4}$ Scientific Officer, Soil \& Water Management Section, HRC, BARI, Gazipur, ${ }^{5}$ Chief Scientific Officer, Regional Horticulture Research Station, Chapai Nawabganj, Bangladesh. 
However, the yield of mango is very low compared to that of India, Pakistan and many other mango growing countries in the world (Hossain and Ahmed, 1994). The causes of the low yields are attributed to biotic and abiotic stress and poor nutrient status of the soil as well as use of imbalanced fertilizers. In Bangladesh, most of the farmers do not follow the modern technology of mango cultivation including manuring. However, yield can be increased considerably by adopting judicious nutrient management and high yielding varieties. Application of N, P and $\mathrm{K}$ fertilizer to mango tree markedly increased the number of fruit/tree, pulp content as well as fruit quality in India (Satapathy and Banik, 2002). The increased fruit yield due to frequent fertilizer application was also reported by Feungchan et al. (1989) and Sharma et al. (2002). In Bangladesh, the mango trees mostly in the homestead and the trees in the orchard hardly receive any fertilizer (Hossain, 1989). But systematic research work on the nutritional requirement for mango has been carried out. Therefore, the present investigation was not the proper combination of fertilizer nutrients in presence of organic manure that promotes better yield and quality fruits of mango.

\section{Materials and Method}

The experiment was conducted at the research field of Regional Horticulture Research Station, Chapai Nawabganj during 2010-11, 2011-12 and 2012-13. The soil of the experimental field was sandy loam in texture having $\mathrm{pH}$ 6.95. Soil samples were collected from the experimental field from a depth of $0-20 \mathrm{~cm}$ prior to application of fertilizers in all the years. Results of soil analysis are presented in Table 1. Organic matter content of the soil was very low. Total N, exchangeable $\mathrm{Ca}, \mathrm{Mn}$ and $\mathrm{Zn}$ were found to be below the critical level. Soil $\mathrm{Mg}$, $\mathrm{K}, \mathrm{P}$ and $\mathrm{S}$ contents were at par with critical level while $\mathrm{B}, \mathrm{Cu}$ and $\mathrm{Fe}$ contents were above the critical level.

Table 1. Chemical properties of experimental soil (average of three years).

\begin{tabular}{|c|c|c|c|c|c|c|c|c|c|c|c|c|}
\hline \multirow{2}{*}{$\mathrm{pH}$} & \multirow{2}{*}{$\mathrm{OM}(\%)$} & $\mathrm{Ca}$ & $\mathrm{Mg}$ & $\mathrm{K}$ & \multirow{2}{*}{$\begin{array}{l}\text { Total } \\
\mathrm{N}(\%)\end{array}$} & $\mathrm{P}$ & $\mathrm{S}$ & B & $\mathrm{Cu}$ & $\mathrm{Fe}$ & $\mathrm{Mn}$ & $\mathrm{Zn}$ \\
\hline & & & $/ 100 \mathrm{~g}$ & soil & & \multicolumn{7}{|c|}{$\mu \mathrm{g} / \mathrm{g}$} \\
\hline 6.95 & 0.74 & 1.53 & 0.81 & 0.27 & 0.037 & 14.0 & 14.2 & 0.78 & 0.35 & 20.2 & 0.79 & 0.55 \\
\hline \multicolumn{2}{|c|}{ Critical level } & 2.0 & 0.80 & 0.20 & - & 14.0 & 14.0 & 0.20 & 0.10 & 1.0 & 5.0 & 2.0 \\
\hline
\end{tabular}

Six treatments consisted of $\mathrm{T}_{1}$ : native nutrient (control), $\mathrm{T}_{2}: \mathrm{N}_{360} \mathrm{P}_{80} \mathrm{~K}_{150} \mathrm{~S}_{50}$, $\mathrm{T}_{3}: \quad \mathrm{N}_{560} \mathrm{P}_{120} \mathrm{~K}_{200} \mathrm{~S}_{70}, \quad \mathrm{~T}_{4}: \quad \mathrm{N}_{760} \mathrm{P}_{160} \mathrm{~K}_{250} \mathrm{~S}_{90}, \quad \mathrm{~T}_{5}: \quad \mathrm{N}_{960} \mathrm{P}_{200} \mathrm{~K}_{300} \mathrm{~S}_{110} \quad$ and $\mathrm{T}_{6}$ : $\mathrm{N}_{1100} \mathrm{P}_{300} \mathrm{~K}_{500} \mathrm{~S}_{120}$ (Farmers practice) $\mathrm{g} /$ tree/year. In addition, $20 \mathrm{~kg}$ cowdung was used to each tree as blanket dose. The experiment was laid out in a randomized complete block design (RCBD) with three replications. Fertilizers N, P, K and S were applied to the field of mango plant and doses were made constant after 18 years age of the plant as urea, triple superphosphate, muriate of potash and 
gypsum, respectively. Full quantity of cowdung was applied to all trees during September. Half of N, P, K and S were applied in mid- September and the remaining quantity was applied in mid- March each year except $\mathrm{T}_{1}$ and $\mathrm{T}_{6}$ treatments. In case of treatment $\mathrm{T}_{6}$, full dose of fertilizers were applied in September. The test variety was BARI Aam-1 (Mahananda). Irrigation, insect and disease control and other intercultural operations were done as and when required. Mature fruits were harvested from first week of June to first week of July during 2011, 2012 and 2013. Fifteen fruits of different sizes and shapes from each tree were randomly selected treatment-wise for data collection. All the data collected on different parameters were analyzed through MSTAT Programme. The Duncan's Multiple Range Test (DMRT) at 5\% level of probability used for mean separations of the studied parameters and yield (Gomez and Gomez, 1984).

\section{Results and Discussion}

Significant variation in fruits/tree, individual fruit weight, fruit length and diameter were observed due to execution of different treatments (Table 2a). Trees grown with no application of fertilizer produced significantly lower number of fruits/tree compared to others. The maximum number of fruits/tree was found in treatment $\mathrm{N}_{960} \mathrm{P}_{200} \mathrm{~K}_{300} \mathrm{~S}_{110} \mathrm{~g} /$ tree and it was statistically different from all other treatments irrespective of years. The weight of individual fruit varied significantly with different treatments in all the years. Maximum fruit weight was recorded with the application of $\mathrm{N}_{760} \mathrm{P}_{160} \mathrm{~K}_{250} \mathrm{~S}_{90}$ g/tree in 2010-11 and 2011-13 and it was statistically identical with $\mathrm{N}_{960} \mathrm{P}_{200} \mathrm{~K}_{300} \mathrm{~S}_{110}$ and $\mathrm{N}_{1100} \mathrm{P}_{300} \mathrm{~K}_{500} \mathrm{~S}_{120}$ g/tree treatments. During 2012-13, treatments $\mathrm{N}_{560} \mathrm{P}_{120} \mathrm{~K}_{200} \mathrm{~S}_{70}$ and $\mathrm{N}_{1100} \mathrm{P}_{300} \mathrm{~K}_{500} \mathrm{~S}_{120}$ $\mathrm{g}$ /tree gave statistically similar fruit weight, which was significantly different from rest of the treatments. Bhuiyan and Irabagon (1992) also obtained larger and heavier fruits due to the effects of fertilization. The lowest fruit weight was noted in control treatment. Application of fertilizer also increased length of fruit significantly, the highest length being noted with $\mathrm{N}_{760} \mathrm{P}_{160} \mathrm{~K}_{250} \mathrm{~S}_{90} \mathrm{~g} /$ tree in 201011 and it was statistically identical with the treatments $\mathrm{N}_{560} \mathrm{P}_{120} \mathrm{~K}_{200} \mathrm{~S}_{70}$, $\mathrm{N}_{960} \mathrm{P}_{200} \mathrm{~K}_{300} \mathrm{~S}_{110}$ and $\mathrm{N}_{1100} \mathrm{P}_{300} \mathrm{~K}_{500} \mathrm{~S}_{120}$ g/tree. During 2011-12 and 2012-13, longest fruit was recorded with application of $\mathrm{N}_{960} \mathrm{P}_{200} \mathrm{~K}_{300} \mathrm{~S}_{110} \mathrm{~g} /$ tree followed by that of $\mathrm{N}_{560} \mathrm{P}_{120} \mathrm{~K}_{200} \mathrm{~S}_{70}$ and $\mathrm{N}_{760} \mathrm{P}_{160} \mathrm{~K}_{250} \mathrm{~S}_{90}$ g/tree. Syamal and Mishra (1989) stated that application of fertilizer had markedly influenced the fruit length. The control treatment receiving no fertilizer produced the shortest fruit. The maximum fruit diameter was found in the treatments $\mathrm{N}_{760} \mathrm{P}_{160} \mathrm{~K}_{250} \mathrm{~S}_{90}$ and $\mathrm{N}_{960} \mathrm{P}_{200} \mathrm{~K}_{300} \mathrm{~S}_{110} \mathrm{~g} /$ tree. These two treatments were significantly different from all other treatments in all the test years. El-Wakeel (2005) indicated that urea at 500 or $1000 \mathrm{~g} \mathrm{~N}$ per tree and potassium sulfate at $400 \mathrm{~g} \mathrm{~K}_{2} \mathrm{O}$ per tree, registered the greatest fruit width in mango (cv. Amrapali) at Dibba Al-Fujira, United Arab Emirates. The minimum fruit diameter was obtained from the control treatment. 


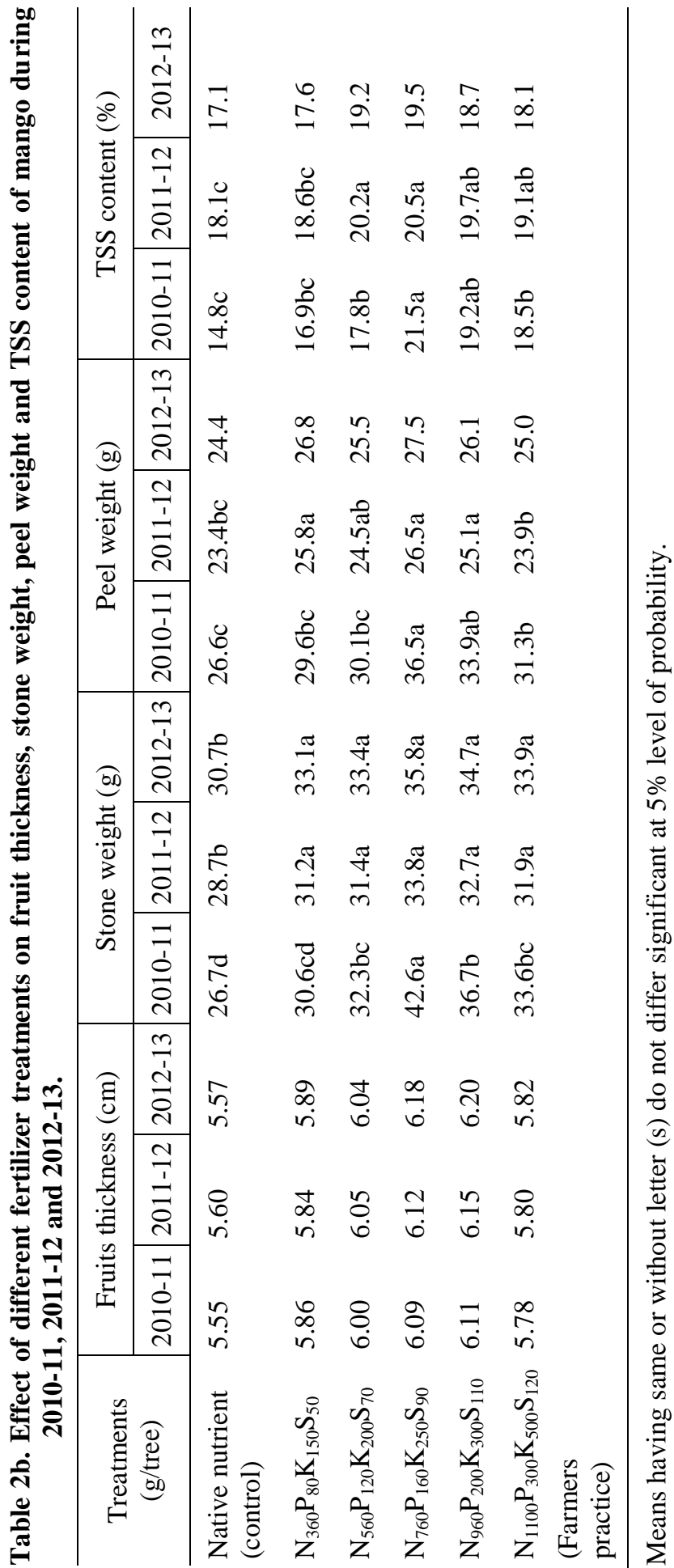


The effect of different nutrients (NPK and S) was also significant on stone weight in all the years but peel weight and TSS content in 2010-11 and 2011-12 years only. Fruit thickness due to application of fertilizer did not differ significantly in any of the test years (Table 2b). Maximum weight of stone was recorded with application of $\mathrm{N}_{760} \mathrm{P}_{160} \mathrm{~K}_{250} \mathrm{~S}_{90} \mathrm{~g} /$ tree treatment, which was significantly different from rest of the treatments in 2010-11. During 2011-12 and 2012-13, maximum weight of stone was found in the treatment $\mathrm{N}_{760} \mathrm{P}_{160} \mathrm{~K}_{250} \mathrm{~S}_{90}$ and it was statistically similar with the treatments $\mathrm{N}_{360} \mathrm{P}_{80} \mathrm{~K}_{150} \mathrm{~S}_{50}$, $\mathrm{N}_{560} \mathrm{P}_{120} \mathrm{~K}_{200} \mathrm{~S}_{70}, \mathrm{~N}_{960} \mathrm{P}_{200} \mathrm{~K}_{300} \mathrm{~S}_{110}$ and $\mathrm{N}_{1100} \mathrm{P}_{300} \mathrm{~K}_{500} \mathrm{~S}_{120} \mathrm{~g} /$ tree. Significant increase in weight of peel was also recorded with $\mathrm{N}_{760} \mathrm{P}_{160} \mathrm{~K}_{250} \mathrm{~S}_{90}$ followed by that of treatment $\mathrm{N}_{960} \mathrm{P}_{200} \mathrm{~K}_{300} \mathrm{~S}_{110} \mathrm{~g} /$ tree. During 2011-1 and 2012-13, maximum peel weight was found in treatment $\mathrm{N}_{760} \mathrm{P}_{160} \mathrm{~K}_{250} \mathrm{~S}_{90} \mathrm{~g} /$ tree and it was statistically identical with $\mathrm{N}_{360} \mathrm{P}_{80} \mathrm{~K}_{150} \mathrm{~S}_{50}, \quad \mathrm{~N}_{560} \mathrm{P}_{120} \mathrm{~K}_{200} \mathrm{~S}_{70}$ and $\quad \mathrm{N}_{960} \mathrm{P}_{200} \mathrm{~K}_{300} \mathrm{~S}_{110}$ g/tree treatments. Total soluble sugar (TSS) content of mango showed almost similar trend or response to peel weight.

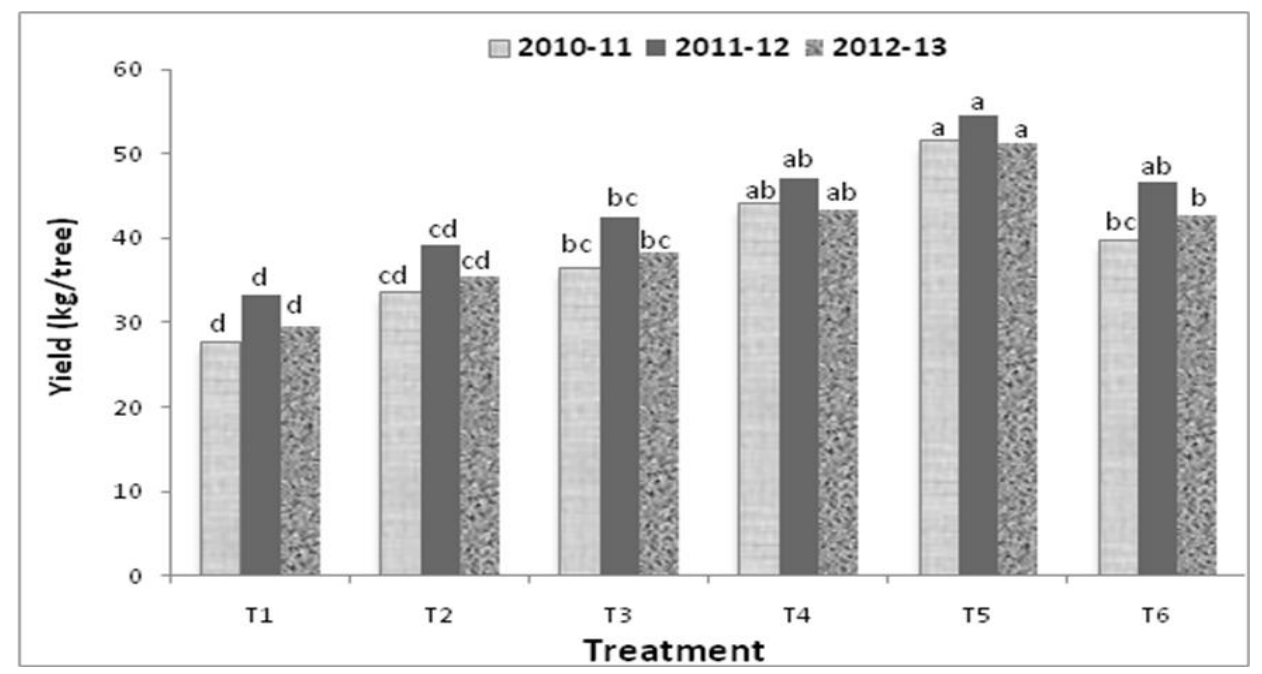

Fig.1. Effect of chemical fertilizer on the yield of mango in 2010-11, 2011-12 and 2012-13 $\left(T_{1}=\right.$ Native nutrient i.e. control, $T_{2}=N_{360} P_{80} K_{150} S_{50}, T_{3}=N_{560} P_{120} K_{200} S_{70}, T_{4}=$ $\mathbf{N}_{760} P_{160} K_{250} S_{90}, T_{5}=N_{960} P_{200} K_{300} S_{110}$ and $T_{6}=N_{1100} P_{300} K_{500} S_{120}$ i.e. farmers practice g/tree/year)

Yield of mango/tree was significantly influenced by different treatment combinations in all the years (Fig.1). Fertilizer application increased yield of mango from 27.79 to $51.78 \mathrm{~kg} /$ tree in $2010-2011,33.30$ to $54.61 \mathrm{~kg} /$ tree in 2011 2012 and 29.44 to $51.15 \mathrm{~kg} /$ tree in 2012-13. Yearly variation in yield of mango/tree was possibly due to climatic factors in different seasons. The highest yield was obtained from the treatments $\mathrm{N}_{960} \mathrm{P}_{200} \mathrm{~K}_{300} \mathrm{~S}_{110} \mathrm{~g} /$ tree and it was statistically identical with treatment $\mathrm{N}_{760} \mathrm{P}_{160} \mathrm{~K}_{250} \mathrm{~S}_{90}$ g/tree in all the years. These two treatments were significantly better than rest of the treatments. Sharma et al. 


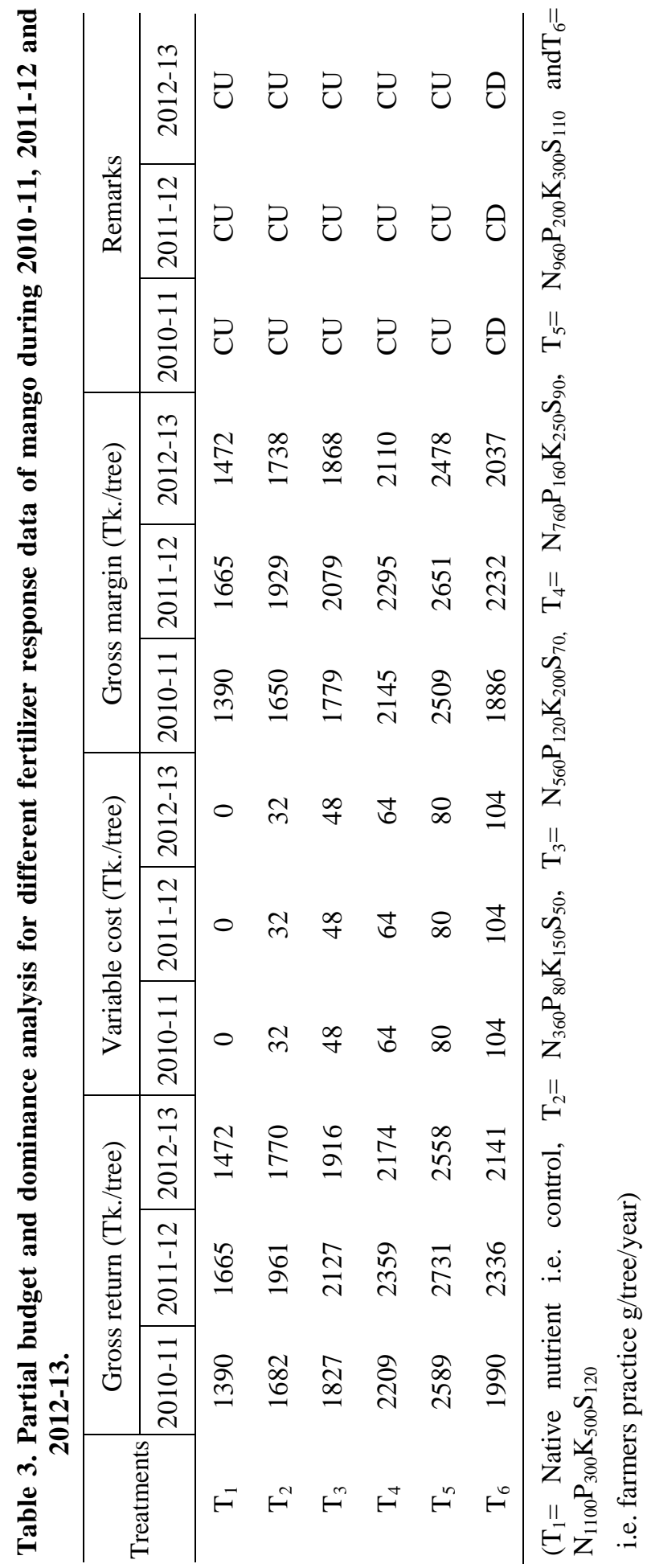




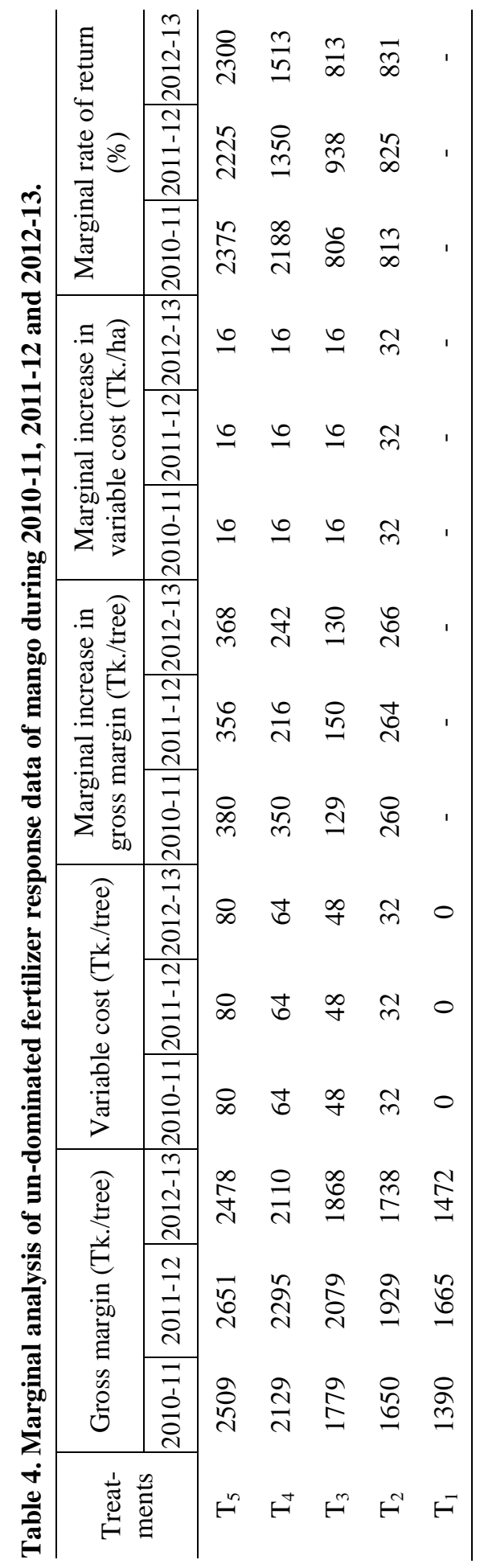


(2000) reported that application of $800 \mathrm{~g} \mathrm{~N}+200 \mathrm{~g} \mathrm{P}+300 \mathrm{~g} \mathrm{~K}$ significantly increased the yield/tree of mango. Suryapananont (1992) also obtained highest yield with $0.5 \mathrm{~kg} \mathrm{~N}+0.4 \mathrm{~kg} \mathrm{P}+1.5 \mathrm{~kg} \mathrm{~K} /$ tree in mango. Hossain (1989) reported that application of cowdung $25 \mathrm{~kg}+$ urea $750 \mathrm{~g}+$ TSP $400 \mathrm{~g}+\mathrm{MoP} 250 \mathrm{~g}+$ gypsum $250 \mathrm{~g}+$ zinc sulphate $15 \mathrm{~g} /$ tree increased the yield of mango. Satapathy and Banik (2002) who opined that application of N, P, and K per mango plant cv. Amrapali per year in West Bengal, India, markedly increased the yield/plant as well as fruit quality.

The maximum yield/tree was produced by $\mathrm{N}_{960} \mathrm{P}_{200} \mathrm{~K}_{300} \mathrm{~S}_{110}$ and $\mathrm{N}_{760} \mathrm{P}_{160} \mathrm{~K}_{250} \mathrm{~S}_{90}$ treatments perhaps supply of sufficient amount of nutrients necessary for better growth and plant development had resulted in higher fruit set and weight. Farmers practice $\left(\mathrm{N}_{1100} \mathrm{P}_{300} \mathrm{~K}_{500} \mathrm{~S}_{120} \mathrm{~g} /\right.$ tree $)$ caused a remarkable reduction in yield of mango by $23 \%$ in $2010-11,15 \%$ in $2011-12$ and $16 \%$ in 2012-13 over treatment $\mathrm{N}_{960} \mathrm{P}_{200} \mathrm{~K}_{300} \mathrm{~S}_{110} \mathrm{~g} /$ tree. It indicated that higher fertilizer levels possibly produced some barrier on nutrition of mango plant or prevalence of other constraints in soil and hence reduced the yield. Plants grown without (native nutrient) added or lower fertilizer produced the lowest yield/tree irrespective of years.

\section{Economic evaluation}

Gross return was calculated from the price of mango. Costs that vary were calculated from the cost involved for fertilizer used for the experimental treatments. The partial budget analysis of fertilizer revealed that the maximum gross margin/tree was achieved with the treatment combination $\mathrm{N}_{960} \mathrm{P}_{200} \mathrm{~K}_{300} \mathrm{~S}_{110}$ in all the years (Table 3). Dominance analysis shows that treatments $\mathrm{N}_{1100} \mathrm{P}_{300} \mathrm{~K}_{500} \mathrm{~S}_{120}$ was cost dominated irrespective of years. Marginal analysis shows that the highest marginal rate of return of $2375 \%$ in $2010-11,2225 \%$ in 2011-12 and 2300\% in 2012-13 was obtained when the crop was fertilized with $\mathrm{N}_{960} \mathrm{P}_{200} \mathrm{~K}_{300} \mathrm{~S}_{110}$ treatment (Table 4). Hence, application of fertilizer at the rate of $\mathrm{N}_{960} \mathrm{P}_{200} \mathrm{~K}_{300} \mathrm{~S}_{110} \mathrm{~g} /$ tree would be economical for better mango production.

\section{Conclusion}

Three years' study revealed that application of $\mathrm{N}_{960} \mathrm{P}_{200} \mathrm{~K}_{300} \mathrm{~S}_{110} \mathrm{~g} /$ tree along with a blanket dose of $20 \mathrm{~kg}$ cowdung/tree is economically optimum for maximizing the yield of mango in Chapai Nawabgonj regions.

\section{References}

BBS (Bangladesh Bureau of statistics). 2012. Statistical Year Book of Bangladesh. Bangladesh Bureau of Statistics, Statistics and Informatics Division, Ministry of Planning, Government of the People's Republic of Bangladesh. Dhaka, Bangladesh. p.146. 
Bhuiyan M. A. J and J.A. Irabagon. 1992. Effect of fertilizer, potassium nitrate sprays and irrigation on the physico-chemical composition of mango (Mangifera indica L.) fruits cv. Carabao. South Indian Hort. 40 (1): 9-15.

El-Wakeel, H. F. 2005. Preliminary studies on fertilization of mango trees under U.A.E. conditions: II - Response of Amrapali mango trees to nitrogen and potassium fertilization. Annals Agric. Sci. 50 (2): 563-572.

Feungchan. S., T. Yimsawat, S. Chindaprasert, N. Hongsbhanich and H. Daito.1989. The effect of the fertilizer application interval on the mango. Kaen Kaset Khon Kaen Agril. J. 17 (2): 100-105.

Gomez, K. A. and A. A. Gomez. 1984. Statistical Procedures for Agricultural Research. $2^{\text {nd }}$ Ed. A Wiley International Scientific Publications, John Wiley and Sons, Newyork. Pp.680

Hossain A. K. M. A. 1989. Manual on Mango Cultivation in Bangladesh. Division of Horticulture, Bangladesh Agricultural Research Institute (BARI), Joydebpur, Gazipur, Pp.40 \& 82.

Hossain A. K. M. A. and A. Ahmed. 1994. A monograph on mango varieties in Bangladesh. HRC-BARI and FAO/UNDP Mango Improvement Project. P.3

Mukherjee, S. K. 1997. Introduction: Botany and Importance. In: The Mango: Botany, Production and Uses. $1^{\text {st }}$ edition (R. E. Litz Ed.), CAB International, Wallingford, UK. Pp.19

Satapathy, S. K. and B. C. Banik. 2002. Studies on nutritional requirement of mango cv. Amrapali. Orissa J. Hort. 30 (1): 59-63.

Sharma, R. C., B. V. C. Mahajan, B. S. Dhillon and A. S. Azad. 2000. Studies on the fertilizer requirements of mango cv. Dashehari in sub-montaneous region of Punjab. Indian J. Agric. Res. 34 (3): 209-210.

Suryapananont, V. 1992. Fertilizer trial on mango cv. Nam Dok in Thailand, Acta Horticulture \# 321, 529-534.

Syamal, M. M. and K. A. Mishra. 1989. Effect of NPK on growth, flowering, fruiting and quality of mango. Acla Horticulture \# 231, 276-281. 